\title{
EFFECT OF CATALYSTS ON THE YIELD AND PROPERTIES OF LIGNIN FROM MICROWAVE-ASSISTED ACETOSOLV EXTRACTION OF OIL PALM EMPTY FRUIT BUNCH FIBRES
}

\section{MUHAMMAD NOR ARIFIN YAAKOB*; RASIDI ROSLAN*; NURJANNAH SALIM*; SITI NOOR HIDAYAH MUSTAPHA $^{*}$; SARANI ZAKARIA ${ }^{* *}$; CHIN-HUA CHIA ${ }^{* *}$ and MOHD SHAIFUL SAJAB ${ }^{\ddagger}$}

\begin{abstract}
Acetosolv is an enhancement organosolv technique utilising acetic acid as solvent and produces high purity of lignin. However, the limitation of this technique in the conventional heating method is the high energy consumption during a long reaction time. Therefore, the employment of microwave is used to overcome this limitation with the expectation of a lower power consumption and short reaction time. In this study, three types of catalysts, sulphuric acid $\left(\mathrm{H}_{2} \mathrm{SO}_{4}\right)$, aluminium choride $\left(\mathrm{AlCl}_{3}\right)$, and chromium nitrate $\left[\mathrm{Cr}\left(\mathrm{NO}_{3}\right)_{3}\right]$ were used to investigate the lignin extraction performance and its properties from microwave-assisted (MWA) acetosolv treatment of oil palm empty fruit bunches (EFB). The highest yields of lignin $(76.98 \%)$ were obtained using an aqueous solution of acetic acid combined with $3.0 \%$ of $\mathrm{H}_{2} \mathrm{SO}_{4}$ under $110^{\circ} \mathrm{C}$ for $30 \mathrm{~min}$. Meanwhile, $\mathrm{AlCl}_{3}$ performed almost similar to $\mathrm{H}_{2} \mathrm{SO}_{4^{\prime}}$ providing lignin yield of $71.57 \%$ at the highest temperature of $110^{\circ} \mathrm{C}$. The usage of microwave-assisted technique also produces a high yield and high purity of lignin. It is also proven that $\mathrm{AlCl}_{3}$ can be a substitute to Bronsted acid for lignin extraction. However, $\mathrm{Cr}\left(\mathrm{NO}_{3}\right)_{3}$ was found not suitable for the lignin's extraction despite having a high potential for cellulose extraction.
\end{abstract}

Keywords: lignocellulose, microwave-assisted, extraction lignin.

Received: 22 March 2020; Accepted: 16 June 2020; Published online: 5 October 2020.

\section{INTRODUCTION}

In recent years, concerns over the continuous depletion of fossil resources as well as an increment

\footnotetext{
Material Technology Programme,

Faculty of Industrial Sciences and Technology,

Universiti Malaysia Pahang,

26300 Gambang, Kuantan, Pahang, Malaysia.

E-mail: rasidi@ump.edu.my

** Bioresources and Biorefinery Laboratory,

Materials Science Programme,

Faculty of Science and Technology,

Universiti Kebangsaan Malaysia,

43600 Bangi, Selangor, Malaysia.

‡ Research Centre for Sustainable Process Technology (CESPRO),

Faculty of Engineering and Built Environment,

Universiti Kebangsaan Malaysia,

43600 Bangi, Selangor, Malaysia.
}

in ecological awareness have drawn a remarkable interest to reduce the dependence on fossil resources as raw materials. Countless research have been conducted to overcome these issues and lignocellulosic biomass has been considered as the best candidate to replace or provide alternative to petroleum-based materials (Amran et al., 2017). This reason is not only for its sustainability but the content of cellulose, lignin and hemicellulose in the biomass provide various functionalities and structures that can be tailored into desired applications. By utilising lignocellulosic biomass, the issues related to petroleum depletion can be prevented as this biomass can be obtained in large quantity at low economical and energy cost (Chen and Lee, 2018). Furthermore, this waste can also be converted into a high-value product, simultaneously solving the waste management problem (Roslan et al., 2014). 
In general, the oil palm empty fruit bunches (EFB) is an organic substrate derived from harvested or processed oil palm fruit bunches (Kheong et al., 2010). These organic substrate is also difficult to degrade biologically (David et al., 2019). In Malaysia, EFB are the colossal solid waste from the oil palm industry and regarded as the most important lignocellulosic biomass for production of chemical and fuels (Coral et al., 2018). The oil palm planted area in 2019 reached 5.90 million hectares, and the production of crude palm oil in the same year was 19.86 million tonnes (MPOB, 2020). The amount of unutilised EFB sent back to landfill is around 40\% (Reeb et al., 2014). There were several reports regarding to the utilisation of the EFB as raw materials for the generation of high value-added products, such as production of cellulose (Aditiawati et al., 2019; Owi et al., 2016), adhesives (Rohimi et al., 2020), activated carbon (Choi et al., 2018; Zaini and Ali, 2018) and composites (Amir et al., 2018). In this study, the effective valorisation of lignin will be the focus on the pursuit of more sustainable and competitive biorefineries.

Basically, oil palm EFB fibre consists about $42 \%$ $63 \%$ cellulose, $21.9 \%-33 \%$ hemicellulose and $10 \%$ $36.6 \%$ lignin (Omar et al., 2011). Lignin is the second most abundant terrestrial organic polymer on earth after cellulose (Fan et al., 2015). Basically, it consists of three types of monolignols, which are p-coumaryl, coniferyl, and synapyl alcohol. It generally has an irregular structure with a highly condensed crosslinked polymer network (Constant et al., 2015). The composition and properties of lignin are influenced by solvent, extraction technique, catalyst, and the nature of the raw material. However, it is regrettable to notice that only a small portion is currently used for value-added product (Sameni et al., 2017).

As a by-product of the pulp and paper industry, lignin is typically extracted by utilising acid or alkali medium to increase the rate of delignification. The raw material is usually heated at elevated temperatures under high pressure by using highpressure reactors or autoclaves. This method is not favourable since it consumes high energy due to the long reaction time, resulting from conductive heating for several hours (Avelino et al., 2018). Therefore, in this study, microwave-assisted (MWA) extraction as the heating method will be introduced to promote the delignification process. Compared to the traditional oven or oil bath convection heating, microwave irradiation utilises the dipole rotation and ionic conduction to heat, and the heating process will occur directly to the targeted sample (Fatriasari et al., 2017; Kappe, 2004; Priecel and Lopez-Sanchez, 2018). This technique can be used as a sustainable methodology for lignin extraction since it operates on low energy consumption due to reduced reaction time and simultaneously increases the efficiency and quality of the product.
In MWA technique, polar compounds must be used in order to absorb the radiation. Therefore, acetosolv technique will be employed as the method of lignin extraction. In addition, acetosolv technique was also chosen as it produces high purity of lignin compared to sulphite and Kraft processes. Sulphite and Kraft will limit the lignin suitability as a resource for future processing and disturb any application that requires 'clean' lignin (Sammons et al., 2013). In this technique, acetic acid was used as a solvent to collapse the plant tissue and promote the lignin degradation from lignocellulosic biomass with the assistance of temperature and acid catalyst (Hernández-Hernández et al., 2016). It can be used to delignify biomass and to remove most of the hemicellulose. Moreover, the lignin extracted from this process also shows excellent properties such as low molecular weight and solubility in organic solvents (Schwiderski et al., 2014). Commonly, aqueous solutions of acetic acid and ethanol combined with low concentrations of Bronsted acids as a catalyst are used to separate lignin and carbohydrates. In general, Bronsted acid is the proton donor substance that donates proton in acid-base reactions such as $\mathrm{H}_{2} \mathrm{SO}_{4}$ and $\mathrm{HCl}$. However, the concentrated $\mathrm{H}_{2} \mathrm{SO}_{4}$ has a drawback, of which expensive materials are needed to fabricate the reaction vessel for anti-corrosion purposes. Therefore, the application of Lewis acid; molecules with incomplete octet of electrons that can accept electrons, in the extraction of lignin as substitute to Bronsted acids will be the main objective in this study (Abdullah et al., 2012).

Therefore, this study is aimed to evaluate the physico-chemical properties of acetosolv lignin (AL) extracted from EFB fibres via MWA acetosolv technique using different Lewis acid catalyst $\left[\mathrm{AlCl}_{3}\right.$ and $\left.\mathrm{Cr}\left(\mathrm{NO}_{3}\right)_{3}\right]$ and compared with commonly used Bronsted acids $\left(\mathrm{H}_{2} \mathrm{SO}_{4}\right)$. The reaction time was fixed at $30 \mathrm{~min}$ to avoid incomplete reaction from occurring below that reaction time.

\section{MATERIALS AND METHOD}

\section{Materials}

EFB were provided by Szetech Engineering Sdn Bhd. The following chemicals were used in the study: sulphuric acid $\left(\mathrm{H}_{2} \mathrm{SO}_{4}, 95 \%-98 \%, \mathrm{R} \& \mathrm{M}\right.$ Chemicals), aluminium chloride ( $\mathrm{AlCl}_{3,}, 98 \%$, SigmaAldrich), chromium nitrate $\mathrm{Cr}\left(\mathrm{NO}_{3}\right)_{3^{3}}, 98 \%$, SigmaAldrich and glacial acetic acid.

\section{MWA Acetosolv Reaction for Lignin Extraction}

The MWA acetosolv was conducted in a $1 \mathrm{~L}$ reaction flask equipped with a reflux system. Several temperatures were studied during the MWA 
which are $90^{\circ} \mathrm{C}, 100^{\circ} \mathrm{C}$ and $110^{\circ} \mathrm{C}$ at a fixed $30 \mathrm{~min}$ reaction time in the presence of $3 \%$ catalyst; $\mathrm{H}_{2} \mathrm{SO}_{4}$, $\mathrm{AlCl}_{3}$ and $\mathrm{Cr}\left(\mathrm{NO}_{3}\right)_{3}$. In these experiments, the EFB to solvent ratio was fixed at $1: 10$, and the reaction took place in a four-neck flat bottom reaction flask containing the acetosolv solution [acetic acid: water solution $(9: 1, \mathrm{v}: \mathrm{v})]$ with the presence of catalysts. After the reaction completed, black liquor was obtained and filtered for separation of residue before being precipitated using deionised water. Finally, the lignin was vacuum filtered, washed with deionised water several times until reaching neutral and dried in an oven for $12 \mathrm{hr}$.

\section{Lignin Extraction Yield and Purity}

Lignin yield was calculated according to Equation (1):

$$
\mathrm{n}=\frac{\mathrm{m} M W A L}{\mathrm{~m} L i g}
$$

Equation (1)

where $n$ is the lignin yield (\%); mMWAL is the mass of lignin extracted in the MWAL process (g) while $\mathrm{mLig}$ is the mass of lignin gained from overall biomass (g) as determined by TAPPI standards (Hames et al., 2008). The purity of lignin was carried out using the National Renewable Energy Laboratory (NREL) standard biomass analytical procedure with three replication.

\section{Characterisation of Lignin}

Scanning electron microscope (SEM). The surface morphology of the raw EFB and residues, the samples were placed on specimen stub, followed by binding with double-sided carbon tape before being observed using FEI Quanta450 SEM with 1000X image magnification.

Fourier transform infrared spectroscopy (FT-IR). FT-IR was performed in a Perkin Elmer Spectrum One under $\mathrm{KBr}$ disc technique. Spectra were acquired between 4000 and $500 \mathrm{~cm}^{-1}$ with a resolution of $4 \mathrm{~cm}^{-1}$. Proton nuclear magnetic resonance $\left({ }^{1} \mathrm{H} \mathrm{NMR}\right)$ was used to support the structural analysis, which was recorded on 500 $\mathrm{MHz}$, Bruker NMR spectrometry. The solvent used was deuterated dimethylsulfoxide, DMSO-d6 and the solvent chemical shift was set and calibrated at $2.5 \mathrm{ppm}$.

Thermogravimetric (TGA) analysis. TGA analysis was performed in a TGA Q500 from the TA instrument. The $15 \mathrm{mg}$ of the sample was heated from $30^{\circ} \mathrm{C}-700^{\circ} \mathrm{C}$ under a nitrogen atmosphere of $40 \mathrm{ml} \mathrm{min}^{-1}$ at a scanning rate of $10^{\circ} \mathrm{C} \mathrm{min}^{-1}$.

\section{RESULT AND DISCUSSION}

Effect of Reaction Temperature and Catalyst on Yield of Crude and Purified Lignin Gained via MWA Acetosolv Treatment

Initially, two parameters were evaluated in this study; the reaction temperature and the catalyst $\left[\mathrm{H}_{2} \mathrm{SO}_{4}, \mathrm{AlCl}_{3}\right.$ and $\left.\mathrm{Cr}\left(\mathrm{NO}_{3}\right)_{3}\right]$, as shown in Figure 1. In acetosolv technique, acetic acid $\left(\mathrm{CH}_{3} \mathrm{COOH}\right)$ was used to produce $\mathrm{H}_{3} \mathrm{O}^{+}$ions, which are responsible for the protonation of ether groups present in lignin; hence, affecting the yield of lignin. However, the ability of these $\mathrm{CH}_{3} \mathrm{COOH}$ to produce the $\mathrm{H}_{3} \mathrm{O}^{+}$ ions is low, and the presence of catalysts is vital for improving this behaviour. From Figure 1, the employment of $\mathrm{Cr}\left(\mathrm{NO}_{3}\right)_{3}$ was not able to extract any lignin. Meanwhile, $\mathrm{AlCl}_{3}$ gave quite the same lignin yield as $\mathrm{H}_{2} \mathrm{SO}_{4}$ at the highest temperature $\left(100^{\circ} \mathrm{C}\right)$ used in this study. It is proven that the yield of lignin is affected by the nature of catalysts used. From a previous study (Avelino et al., 2018; Schwiderski et al., 2014), $\mathrm{AlCl}_{3}$ showed quite a similar yield to Bronsted acids as it has similar acidic power despite the effect of higher cation hardness compared to other Lewis acids. This acidic power leads to more efficient coordination with the oxygen atoms present in the ether groups and making them more susceptible to hydrolysis. Therefore, these results support the fact that the acidic power also has a significant influence on yield, but not so much in the lignin purity, as shown in Figure 1. For $\mathrm{Cr}\left(\mathrm{NO}_{3}\right)_{3}$, the only possible reason that can be explained to the absence of lignin is that $\mathrm{Cr}$ is adsorbed on the lignin fragment since lignin has a higher affinity for $\mathrm{Cr}(\mathrm{III})$ before the precipitation process being done. This high affinity eventually leads to the formation of water repellent lignin (Garcia-Reyes and RangelMendez, 2009; Pandey et al., 1998; Wu et al., 2008).

The lignin yield based on reaction temperature was increased with the increased temperature. From Figure 1, it is shown that as temperature increased from $90^{\circ} \mathrm{C}-110^{\circ} \mathrm{C}$, the lignin yield obtained had also increases from $43.07 \%-76.98 \%$, with the highest purity of $94.15 \%$ for $\mathrm{H}_{2} \mathrm{SO}_{4}$. As for $\mathrm{AlCl}_{3}$, the yield increased from $28.81 \%-71.57 \%$, with an increment of purity from $83.39 \%-92.89 \%$. Basically, temperature plays a vital role in lignin extraction as it enhances the degradation of cell walls while the lignin and hemicellulose were decomposed and dissolved in the organic solvent (Amran et al., 2017; 2019). The higher yield obtained was also due to the extensive lignin depolymerisation which led to higher lignin solubilisation in the organic solvent, especially with the presence of microwave irradiation (MonteilRivera et al., 2012). Theoretically, microwave irradiation provides the homogeneity of temperature in the reactor compared with conventional heating and, consequently, facilitated the cleavage of the 


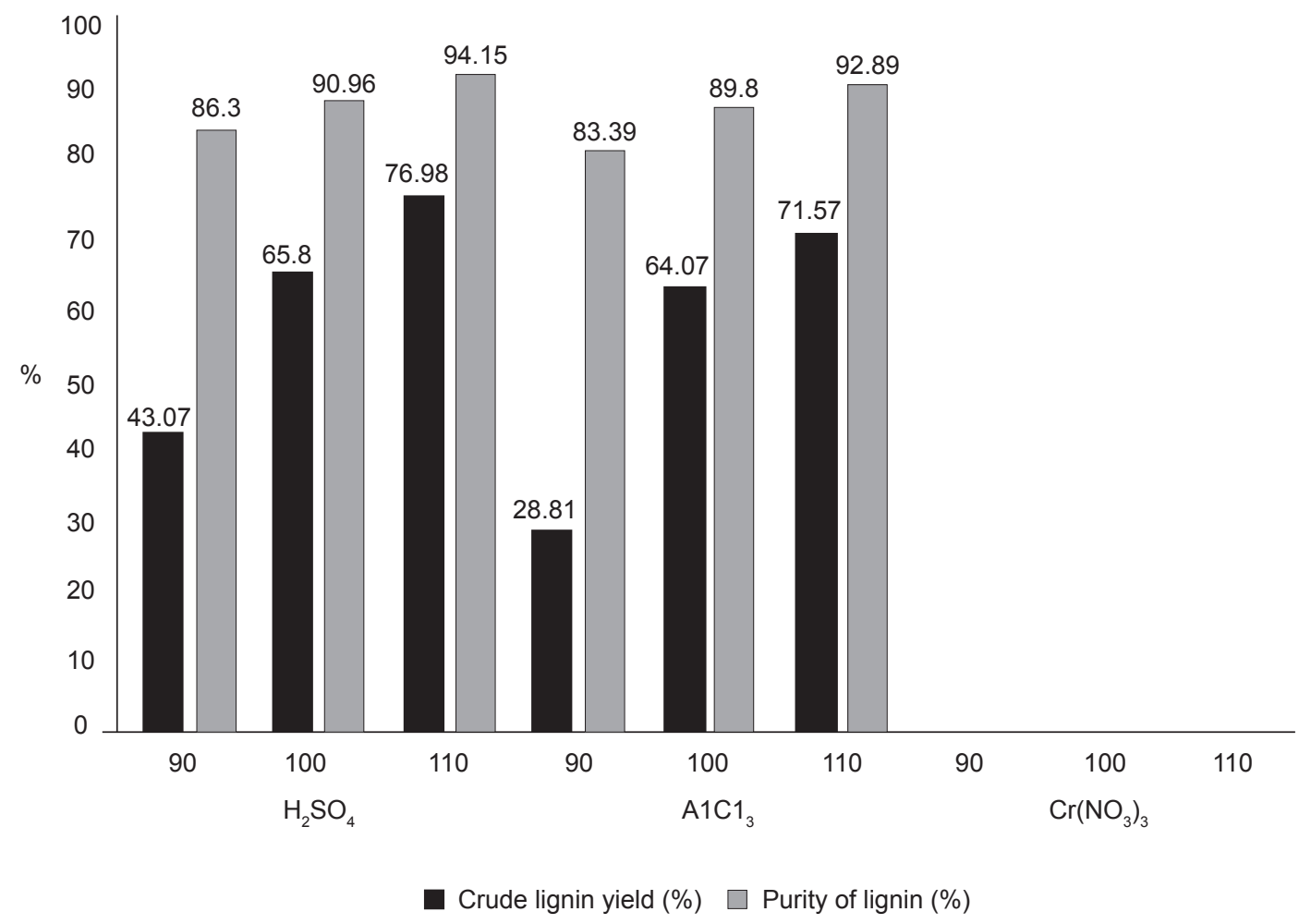

Figure 1. The percentage of crude lignin and purity of lignin by sulphuric acid $\left(\mathrm{H}_{2} \mathrm{SO}_{4}\right)$, aluminium chloride $\left(\mathrm{AlCl}_{3}\right)$ and chromium (III) nitrate $\left[\mathrm{Cr}\left(\mathrm{NO}_{3}\right)_{3}\right]$

$\mathrm{C}-\mathrm{C}$ bond which led to the higher yield of lignin extracted from EFB.

\section{Morphological Observation of Oil Palm EFB Fibres Before and After MWA Acetosolv}

The morphology of the EFB fibre and EFB residue are shown in Figure 2. In general, the SEM results showed that the EFB fibre's morphology is made up of distinct cell wall layers. For the EFB residues, the acetosolv technique has changed the morphology of EFB fibres due to the removal of lignin. At the lowest temperature $\left(90^{\circ} \mathrm{C}\right)$, it can be seen that the morphology of the fibre undergoes a little change as the acetosolv technique had roughened the structure of cell wall surface of the fibre which disrupted the lignin's structure (Tajuddin et al., 2019; Yaakob et al., 2020). This generally occurred to all the catalysts used in this study. At medium temperature $\left(100^{\circ} \mathrm{C}\right)$, the cell wall is continuously removed from the structure of the fibres for all the residues. At the highest temperature $\left(110^{\circ} \mathrm{C}\right)$, all the residues have a different morphology based on the catalyst used. For the $\mathrm{H}_{2} \mathrm{SO}_{4}$ catalyst, it was clearly observed that the cell wall of the fibres was completely removed and exposed to the defibrated inner microfibrils, as shown in Figure $2 d$. Compared to $\mathrm{H}_{2} \mathrm{SO}_{4}$, Figure $2 g$ showed the appearance of spherical droplets on the surface at the highest temperature $\left(110^{\circ} \mathrm{C}\right)$ for $\mathrm{AlCl}_{3}$ residues. The presence of this spherical droplet can be explained due to the derivation of dehydrated carbohydrates and resulting in the formation of lignin-like materials (Shen et al., 2016). From Figure $2 j$, it is noticed that the separation of fibres bundles into individual fibres had taken place in $\mathrm{Cr}\left(\mathrm{NO}_{3}\right)_{3}$ residue. The formation of these individual fibres can be explained by the mechanism of the dissociation of $\mathrm{Cr}^{3+}$ ions into a coordination complex structure with water molecules $\left(\mathrm{H}_{2} \mathrm{O}\right)$ at the initial hydrolysis stage. This finding also proves the successive hydrolysis treatment initiated by the $\mathrm{Cr}\left(\mathrm{NO}_{3}\right)_{3}$ in the dissolution of the less-ordered defective crystalline regions (Chen et al., 2017).

\section{Determination of Chemical Structural Using FT-IR}

Basically, the structural properties of lignin are affected by the raw material origin, the environmental conditions, and the method to extract the lignin itself. Figure 3 presented the FT-IR spectra that were used to investigate the functional group of the acetosolv lignin at various temperatures with different catalysts. In general, the spectra showed that there are no significant differences in terms of functional groups, and the spectra can be explained by dividing into two regions; the backbone region and the lignin-carbohydrates complexes regions. 
In the backbone region, the functional groups related to lignin aromatic ring skeleton usually occur at the band around 1600 and $1500 \mathrm{~cm}^{-1}$ (Watkins et al., 2015). In this study, these bands were observed at $1594 \mathrm{~cm}^{-1}$ and $1513 \mathrm{~cm}^{-1}$ by the presence of $\mathrm{C}=\mathrm{C}$ stretching of the aromatic ring skeleton, $1463 \mathrm{~cm}^{-1}$ for the C-H deformations, and aromatic skeletal vibrations coupled with $\mathrm{C}-\mathrm{H}$ in-plane deformation at $1425 \mathrm{~cm}^{-1}$. As the lignin is not $100 \%$ pure, the presence of the lignin-carbohydrate complexes can be seen by the signals observed at 1714, 1269, 1165 and $1125 \mathrm{~cm}^{-1}$ which represent the existence of $\mathrm{C}=\mathrm{O}$ stretching that is generally attributed to lignincarbohydrate complexes (LCC) (Avelino et al., 2018).

In general, there is no significant damage occurring on the lignin during the acetosolv process since the basic aromatic lignin is present as in Figure 3 . The presence of syringyl unit can be seen at band 1329 and $1125 \mathrm{~cm}^{-1}$, while at band 1513 and $1269 \mathrm{~cm}^{-1}$ showed the existence of guaiacyl units in the lignin and the band at $851 \mathrm{~cm}^{-1}$ was assigned to $\mathrm{C}-\mathrm{H}$ out-ofplane in positions 2, 5 and 6 of guaiacyl units.

\section{${ }^{1}$ HNMR Analysis}

Figure 4 presents the ${ }^{1} \mathrm{HNMR}$ spectra of MWA acetosolv lignin with the presence of a different acid catalyst at various temperatures. The sharp peak shown at the range of 2.33-2.51 ppm is the solvent used; DMSO-d6 to solubilise lignin for the sample preparation phase. The presence of aliphatic moiety is shown at the signals between 0.8 and $1.5 \mathrm{ppm}(\mathrm{Li}$ et al., 2018). The methoxyl proton can be observed by the presence of a signal between 3.1 and $4.0 \mathrm{ppm}$. The complex signals at 3.0-4.5 also confirmed the presence of free polysaccharide moieties in the lignin (Abdelkafi et al., 2011). At 3.20 ppm, it can be seen that the signal of $-\mathrm{CH}_{2}$ linkages in the hydroxymethyl chain of the lignin was strong in all lignin except for HL100 and HL110. The possible explanation for this occurrence is due to the catalyst efficiency used at high temperature. Above $100^{\circ} \mathrm{C}$, the hydrolysis reaction which occurred with the presence of $\mathrm{H}_{2} \mathrm{SO}_{4}$ are capable of breaking the lignin cellulose complex (LCC) bond effectively without leaving the $\mathrm{CH}_{2}$

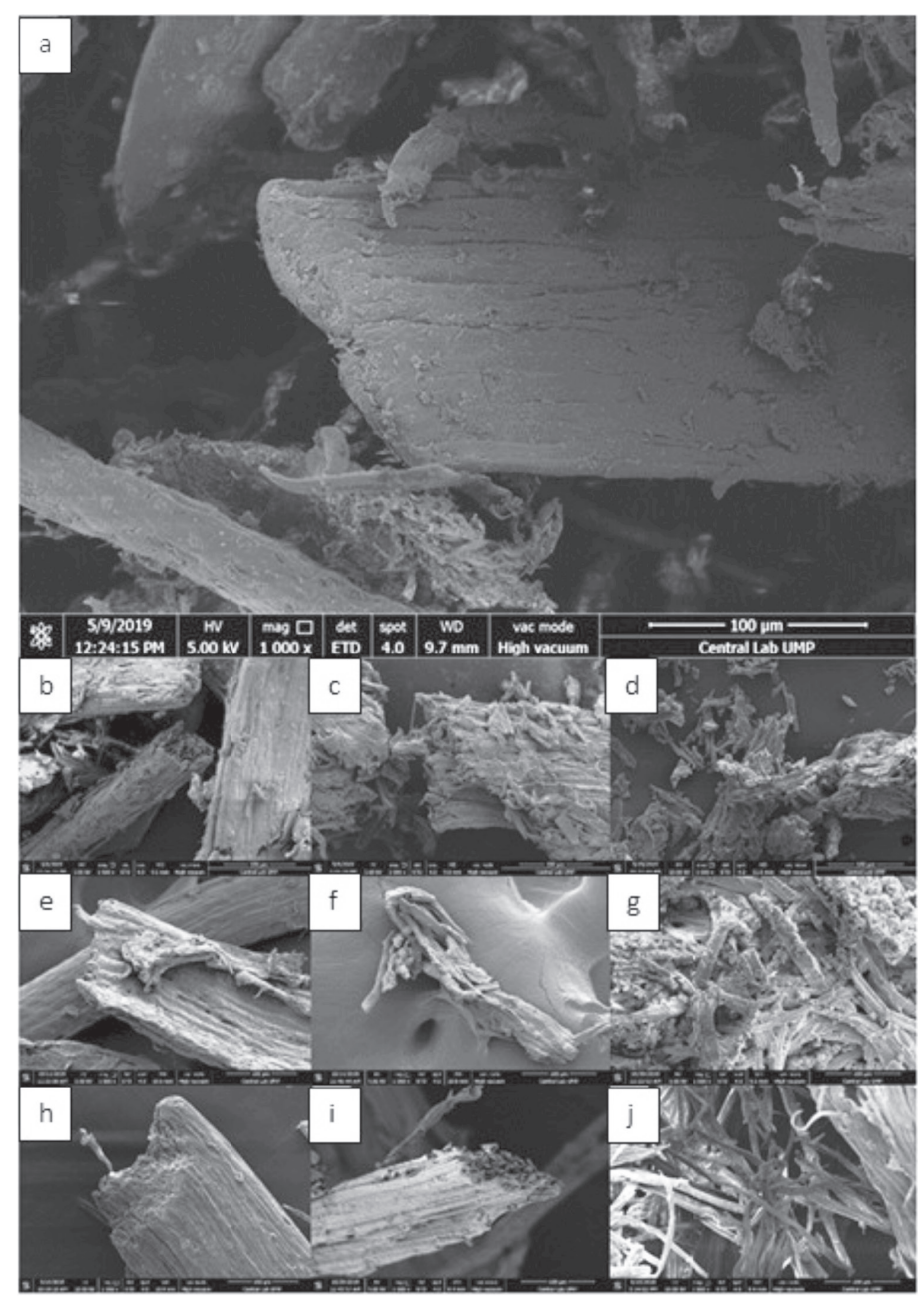

Figure 2. Scanning electron microscopy (SEM) image of a) native empty fruit bunches (EFB) and residues after microwave-assisted (MWA) acetosolv in the presence of b) at $90^{\circ} \mathrm{C}$, c) $\mathrm{H}_{2} \mathrm{SO}_{4}$ at $100^{\circ} \mathrm{C}$, d) $\mathrm{H}_{2} \mathrm{SO}_{4}$ at $110^{\circ} \mathrm{C}$, e) $\mathrm{AlCl}_{3}$ at $90^{\circ} \mathrm{C}$, f) $\mathrm{AlCl}_{3}$ at $100^{\circ} \mathrm{C}, \mathrm{g}$ ) $\mathrm{AlCl}_{3}$ at $\left.110^{\circ} \mathrm{C}, \mathrm{h}\right) \mathrm{Cr}\left(\mathrm{NO}_{3}\right)_{3}$ at $90^{\circ} \mathrm{C}$, i) $\mathrm{Cr}\left(\mathrm{NO}_{3}\right)_{3}$ at $100^{\circ} \mathrm{C}$ and j) $\mathrm{Cr}\left(\mathrm{NO}_{3}\right)_{3}$ at $110^{\circ} \mathrm{C}$. 


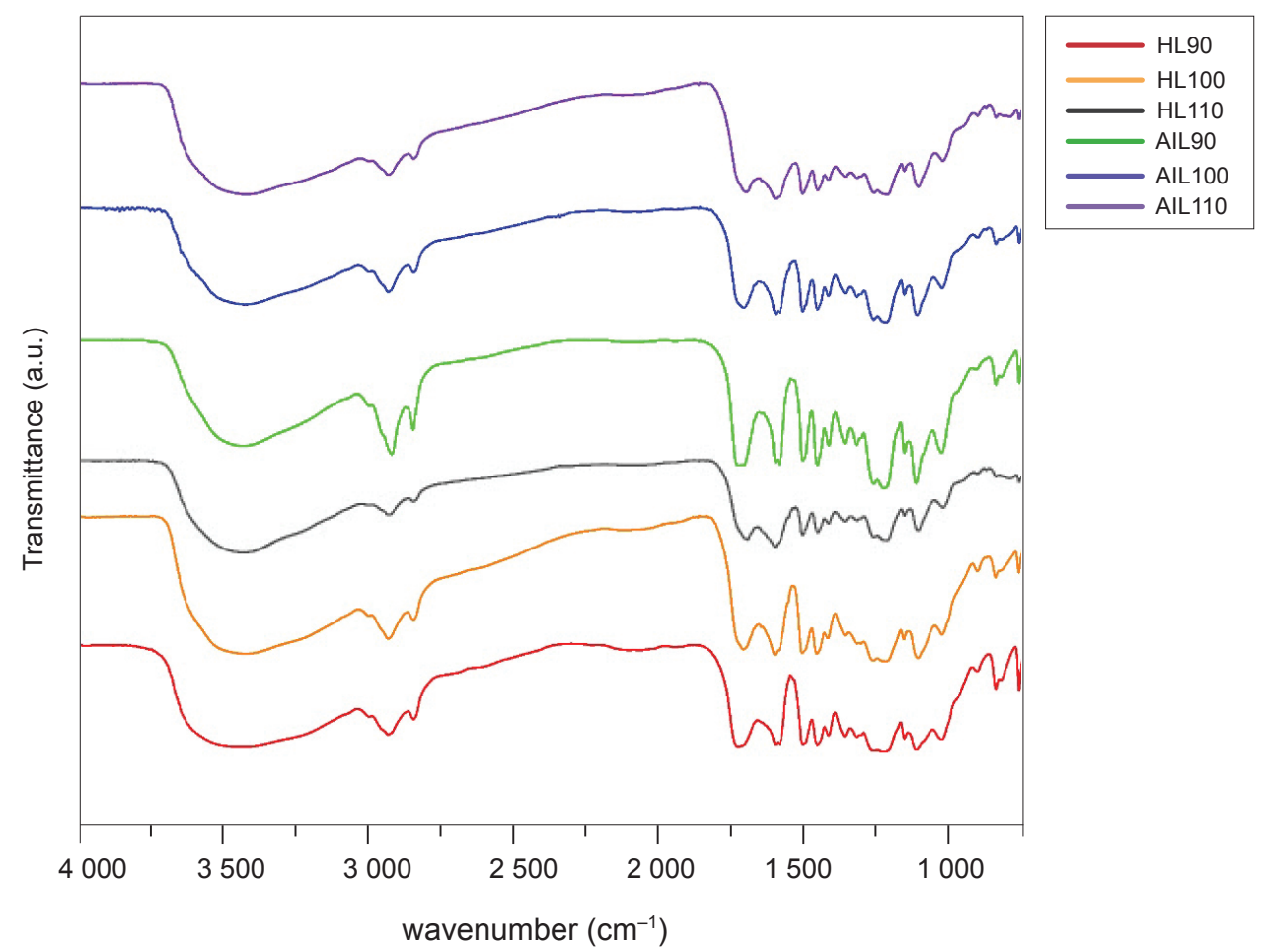

Figure 3. Fourier transform infrared (FT-IR) spectra for microwave-assisted (MWA) acetosolv lignin in the presence of $\mathrm{H}_{2} \mathrm{SO}_{4}$ at $90^{\circ} \mathrm{C}(\mathrm{HL} 90)$, $100^{\circ} \mathrm{C}(\mathrm{HL100})$ and $110^{\circ} \mathrm{C}(\mathrm{HL110})$ and $\mathrm{AlCl}_{3}$ at $90^{\circ} \mathrm{C}(\mathrm{AlL} 90), 100^{\circ} \mathrm{C}$ (AlL100) and $110^{\circ} \mathrm{C}$ (AlL110).

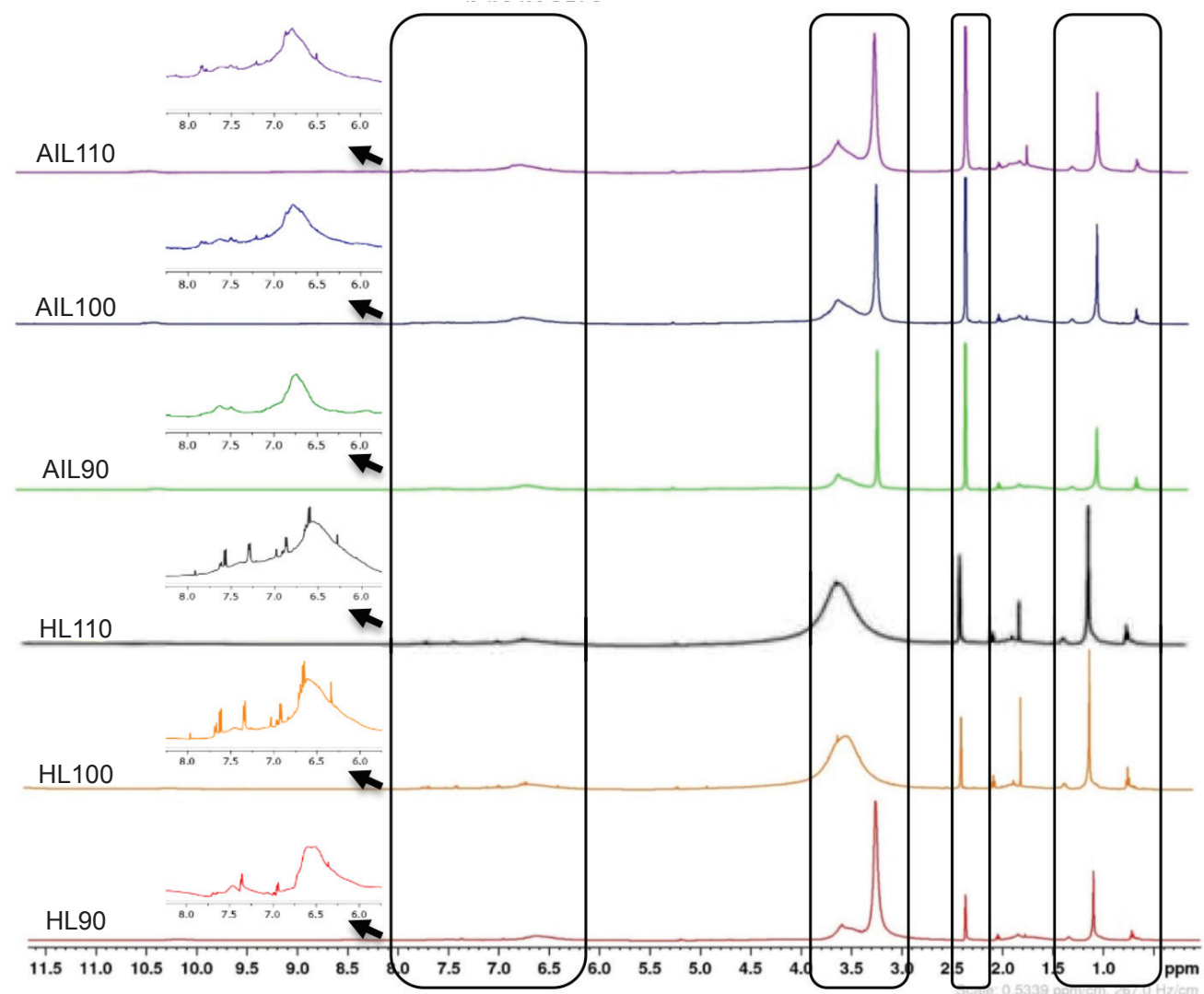

Figure 4. Proton nuclear magnetic resonance ( $\left.{ }^{1} H N M R\right)$ of microwave-assisted (MWA) acetosolv lignins. 
linkage on the lignin structure. The $\beta-\mathrm{O}-4$ structures in the lignin are shown between 5.9-6.6 ppm and the active proton at $\mathrm{C} 5$ position was also observed at signal around $6.96 \mathrm{ppm}$ (Li et al., 2018; Hussin et al., 2013; Rashid et al., 2018). The presence of signals between 6.0 and $8.9 \mathrm{ppm}$ indicates the presence of aromatic protons in the lignin's unit (Rashid et al., 2018).

\section{Thermal Decomposition of Acetosolv Lignin}

The decomposition of lignin in this work was investigated using TGA under nitrogen flow, and the percentage of lignin weight loss in relation to temperature was revealed by the TGA curves, as shown in Figure 5. From this result, it is shown that the decomposition stages of lignin can be divided into three stages from $30^{\circ} \mathrm{C}-800^{\circ} \mathrm{C}$. The first stage started below $100^{\circ} \mathrm{C}$, where the evaporation of water, carbon dioxide, and carbon monoxide occurred. The second decomposition stage referred to the remaining lignin-carbohydrate complex (LCC) and hemicellulose at the range of $200^{\circ} \mathrm{C}-350^{\circ} \mathrm{C}$ (Hashim et al., 2016; Watkin et al., 2015). The final stage occurred at a temperature above $400^{\circ} \mathrm{C}$ due to the cleavage of the monomeric unit bond lead to the degradation of volatile products such as phenolic and alcohol derived from lignin. Therefore, in general, the wide range of the lignin decomposition is a result of the various branching of the lignin molecular structure. In terms of catalyst effect on the thermal stability of the lignin, the TGA curve proved the ability of the catalyst in removing the bonding in LCC as thermal stability is directly proportional to the purity of the lignin. Therefore, in this study, it is observed that the thermal stability for all lignin has no significant difference as the purity of the lignin in all parameter is quite similar.

\section{CONCLUSION}

High purity lignin was successfully obtained from oil palm EFB via MWA acetosolv process with a high yield of crude lignin. It is shown that the yield of lignin obtained via utilisation of Bronsted acid $(76.98 \%)$ is slightly higher compared to utilisation of Lewis acid $(71.57 \%)$ and it is noted that chromium (III) nitrate is not suitable for extraction of lignin but has a high potential for production of cellulose. The extraction process with different acid catalysts produced lignin with similar structural and thermal properties. Moreover, the extraction of lignin can be done using a simple and time-saving method, as presented by the MWA acetosolv process.

\section{ACKNOWLEDGEMENT}

The authors gratefully acknowledge and thank Universiti Malaysia Pahang for financial support via internal grant RDU190330. The authors would also like to acknowledge the Postgraduate Research Grant Scheme (PGRS1903195) and the Faculty of Industrial Sciences and Technology for the support given via its Master Research Scheme (MRS) in this work.

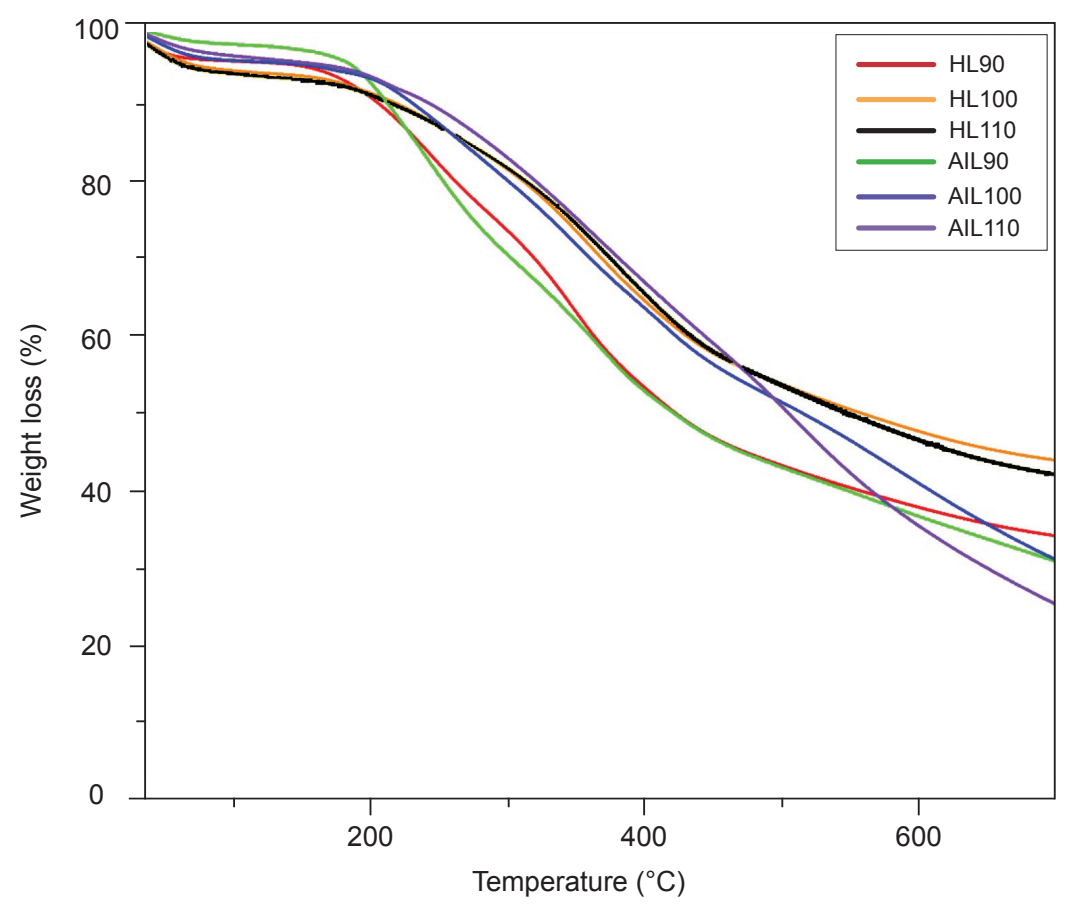

Figure 5. Thermogravimetric analysis (TGA) curves of lignins gained for different acid catalyst and at different temperatures. 


\section{REFERENCES}

Abdullah, N; Mohd Ismail, H B; Abu Bakar, N $\mathrm{H}$ and Michael, L (2012). College Matriculation Chemistry SK016. SAP Education.

Abdelkafi, F; Ammar, H; Rousseau, B; Tessier, M; El Gharbi, R and Fradet, A (2011). Structural analysis of alfa grass (Stipa tenacissima 1.) lignin obtained by acetic acid/formic acid delignification. Biomacromolecules, 12(11): 3895-3902.

Aditiawati, P; Dungani, R; Fikri; R M and Hartati, $S$ (2019). Optimization of cellulose nanofiber production from oil palm empty fruit bunch using Trichoderma sp. with the solid state fermentation method. Bioresources, 14(2): 3688-3700.

Amir, S M M; Sultan, M T H; Jawaid, M; Ariffin, A H; Ishak, M R; Reussmazran Yusof, M; Mohd, S and Salleh, K A M (2018). Effect of gamma radiation on compressive properties of kevlar/oil palm empty fruit bunch hybrid composites. Bioresources, 13(4): 7628-7639.

Amran, U A; Zakaria, S; Chia, C H; Roslan, R; Jaafar, S N and Salleh, K M (2019). Polyols and rigid polyurethane foams derived from liquefied lignocellulosic and cellulosic biomass. Cellulose, 26(5): 3231-3246.

Amran, U A; Zakaria, S; Chia, C H; Fang, Z and Masli, M Z (2017). Production of liquefied oil palm empty fruit bunch based polyols via microwave heating. Energy and Fuels, 31(10): 10975-10982.

Avelino, F; Da Silva, K T; De Souza Filho, M D S M; Mazzetto, S E and Lomonaco, D (2018). Microwaveassisted organosolv extraction of coconut shell lignin by Bronsted and Lewis acids catalysts. J. Cleaner Production, 189: 785-796.

Chen, Y; Tan, T; Lee, H and Abd Hamid, S (2017). Easy fabrication of highly thermal-stable cellulose nanocrystals using $\mathrm{Cr}\left(\mathrm{NO}_{3}\right)_{3}$ catalytic hydrolysis system: A feasibility study from macro- to nanodimensions. Materials, 10(1): 42.

Chen, Y W and Lee, H V (2018). Revalorization of selected municipal solid wastes as new precursors of 'green' nanocellulose via a novel one-pot isolation system: A source perspective. Int. J. Biological Macromolecules, 10: 778-792.

Choi, M S; Park, S; Lee, H and Park, H S (2018). Hierarchically nanoporous carbons derived from empty fruit bunches for high performance supercapacitors. Carbon Letters, 25(1): 103-112.
Constant, S; Basset, C; Dumas, C; Di Renzo, F; Robitzer, M; Barakat, A and Quignard, F (2015). Reactive organosolv lignin extraction from wheat straw: Influence of Lewis acid catalysts on structural and chemical properties of lignins. Industrial Crops and Products, 65: 180-189.

Coral Medina, J D; Woiciechowski, A L; Filho, A Z; Brar, S K; Magalhães Júnior, A I and Soccol, C R (2018). Energetic and economic analysis of ethanol, xylitol and lignin production using oil palm empty fruit bunches from a Brazilian factory. J. Cleaner Production, 19: 544-550.

David Castano, J; Camilo Crespo, C and Torres, E (2019). Evaluation of chemical and biological treatments to degrade oil palm empty fruit bunches (Elaeis guineensis Jacq.) and their potential use. J. Oil Palm Res. Vol. 31(2): 271-280.

Fan, L; Ruan, R; Liu, Y; Wang, Y and Tu, C (2015). Effects of extraction conditions on the characteristics of ethanol organosolv lignin from bamboo (Phyllostachys pubescens Mazel). BioResources, 10(4): 7998-8013.

Fatriasari, W; Anita, S H and Risanto, L (2017). Microwave assisted acid pretreatment of oil palm empty fruit bunches (EFB) to enhance its fermentable sugar production. Waste and Biomass Valorization, 8(2): 379-391.

Garcia-Reyes, R B and Rangel-Mendez, J R (2009). Contribution of agro-waste material main components (hemicelluloses, cellulose, and lignin) to the removal of chromium (III) from aqueous solution. J. Chemical Technology and Biotechnology, 84(10): 1533-1538.

Hames, B; Ruiz, R; Scarlata, C; Sluiter, A and Templeton, D (2008). Preparation of Sample for Compositional Analysis: Laboratory Analytical Procedures (LAP). 12 pp.

Hashim, S N A S; Zakaria, S; Chia, C H; Pua, F L and Syed Jaafar, S N (2016). Chemical and Thermal Properties of Purified Kenaf Core and Oil Palm Empty Fruit Bunch Lignin. p. 451653.

Hernández-Hernández, H M; Chanona-Pérez, J J; Vega, A; Ligero, P; Mendoza-Pérez, J A; CalderónDomínguez, G; Terrés, E and Farrera-Rebollo, R R (2016). Acetosolv treatment of fibers from waste agave leaves: Influence of process variables and microstructural study. Industrial Crops and Products, 86: 163-172.

Hussin, M H; Rahim, A A; Mohamad Ibrahim, M N and Brosse, N (2013). Physicochemical 
characterization of alkaline and ethanol organosolv lignins from oil palm (Elaeis guineensis) fronds as phenol substitutes for green material applications. Industrial Crops and Products, 49: 23-32.

Kappe, C O (2004). Controlled microwave heating in modern organic synthesis. Angewandte Chemie International Edition, 43(46): 6250-6284.

Kheong, L V; Rahman, Z A; Musa, M H and Hussein, A (2010). Empty fruit bunch application and oil palm root proliferation. J. Oil Palm Res. Vol. 22(1): 749-757.

Li, J; Zhang, J; Zhang, S; Gao, Q; Li, J and Zhang, W (2018). Alkali lignin depolymerization under eco-friendly and cost-effective $\mathrm{NaOH} /$ urea aqueous solution for fast curing bio-based phenolic resin. Industrial Crops and Products. p. 12025-33.

Monteil-Rivera, F; Huang, G H; Paquet, L; Deschamps, S; Beaulieu, C and Hawari, J (2012). Microwave-assisted extraction of lignin from triticale straw: Optimization and microwave effects. Bioresource Technology. p. 775-782.

MPOB (2020). Overview of the Malaysian oil palm industry 2019. Available from: http:/ / www.mpob. gov.my.

Omar, R; Idris, A; Yunus, R; Khalid, $\mathrm{K}$ and Aida Isma, M I (2011). Characterization of empty fruit bunch for microwave-assisted pyrolysis. Fuel, 90(4): 1536-1544.

Owi, W T; Lin, O H; Sam, S T; Chia, C H; Zakaria, S; Mohaiyiddin, M S; Villagracia, A $\mathrm{R}$ and Akil, H M (2016). Comparative study of microcelluloses isolated from two different biomasses with commercial cellulose. Bioresources, 11(2): 3453-3465.

Pandey, K K; Chaohan, S S and Aggarwal, P K (1998). Reaction of wood with inorganic salts. Holz als Roh-und Werkstoff, 56(6): 412-415.

Priecel, P and Antonio Lopez-Sanchez, J (2018). Advantages and limitations of microwave reactors: From chemical synthesis to the catalytic valorization of biobased chemicals. ACS Sustainable Chemistry and Engineering, 7(1): 3-21.

Rashid, T; Gnanasundaram, N; Appusamy, A; Kait, C F and Thanabalan, M (2018). Enhanced lignin extraction from different species of oil palm biomass: Kinetics and optimization of extraction conditions. Industrial Crops and Products, 116: 123136.
Reeb, C W; Hays, T; Venditti, R A; Gonzalez, $\mathrm{R}$ and Kelley, S (2014). Supply chain analysis, delivered cost, and life cycle assessment of oil palm empty fruit bunch biomass for green chemical production in Malaysia. Bioresources, 9(3): 5385-5416.

Rohimi, N F; Roslan, R; Salim, N; Mustapha, S N H; Zakaria, S and Chia, C H (2020). Ligninbased polybenzoxazine derived from empty fruit bunch fibers with good thermal and mechanical properties. Materials Science Forum Vol. 981: 121-126.

Roslan, R; Zakaria, S; Chia, C H; Boehm, R and Laborie, M P (2014). Physico-mechanical properties of resol phenolic adhesives derived from liquefaction of oil palm empty fruit bunch fibres. Industrial Crops and Products, 62: 119-124.

Sameni, J; Krigstin, S and Sain, M (2017). Solubility of lignin and acetylated lignin in organic solvents. BioResources, 12(1): 1548-1565.

Sammons, R J; Harper, D P; Labbé, N; Bozell, J J; Elder, T and Rials, T G (2013). Characterization of organosolv lignins using thermal and FT-IR spectroscopic analysis. BioResources, 8(2): 27522767.

Schwiderski, M; Kruse, A; Grandl, R and Dockendorf, D (2014). Comparison of the influence of a Lewis acid $\mathrm{AlCl}_{3}$ and a Bronsted acid $\mathrm{HCl}$ on the organosolv pulping of beech wood. Green Chemistry, 16(3): 1569.

Shen, X -J; Wang, B; Huang, P -L; Wen, J -L and Sun, R-C (2016). Effects of aluminum chloride-catalyzed hydrothermal pretreatment on the structural characteristics of lignin and enzymatic hydrolysis. Bioresource Technology, 22: 657-664.

Tajuddin, A M; Harun, S; Sajab, M S; Zubairi, S I; Jahim, J; Markom, M; Nor, M T M; Abdullah, M A and Hashim, N (2019). Influence of deep eutectic solvent (DES) pretreatment on various chemical composition of empty fruit bunch (EFB). Int. J. Engineering and Technology Vol. 8 No. 1.2: 66-74.

Watkins, D; Nuruddin, Md; Hosur, M; TcherbiNarteh, A and Jeelani, S (2015). Extraction and characterization of lignin from different biomass resources. J. Materials Research and Technology, 4(1): 26-32.

Wu, Y; Zhang, S; Guo, X and Huang, H (2008). Adsorption of chromium(III) on lignin. Bioresource Technology, 99(16): 7709-7715. 
Yaakob, M N A; Roslan, R; Salim, N; Mustapha, S N H; Zakaria, S; Chia, C H; Sajab, M S and Yek, P N Y (2020). Effect of temperature on the yield of lignin extracted using microwave-assisted acetosolv from empty fruit bunch fibers. Materials Science Forum, 981: $240-244$
Zaini, M A A and Ali, A H (2018). Adsorptive characteristics and microwave dielectric properties of oil palm empty fruit bunch-based activated carbons for dye removal. Malaysian J. Fundamental and Applied Sciences, 14(2): 241-245.

\section{JOURNAL OF OIL PAMM RESEARCH Microsite}

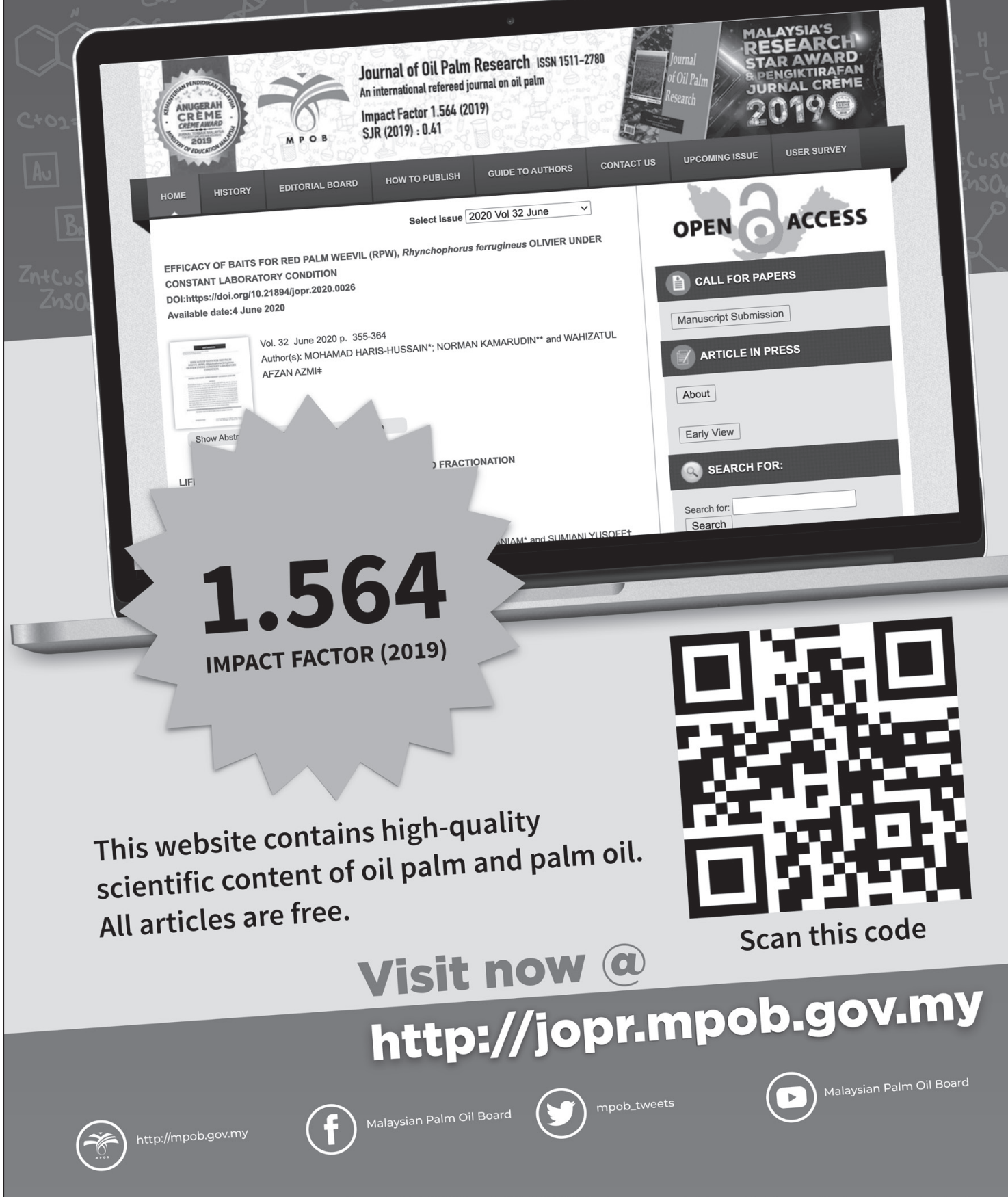

